
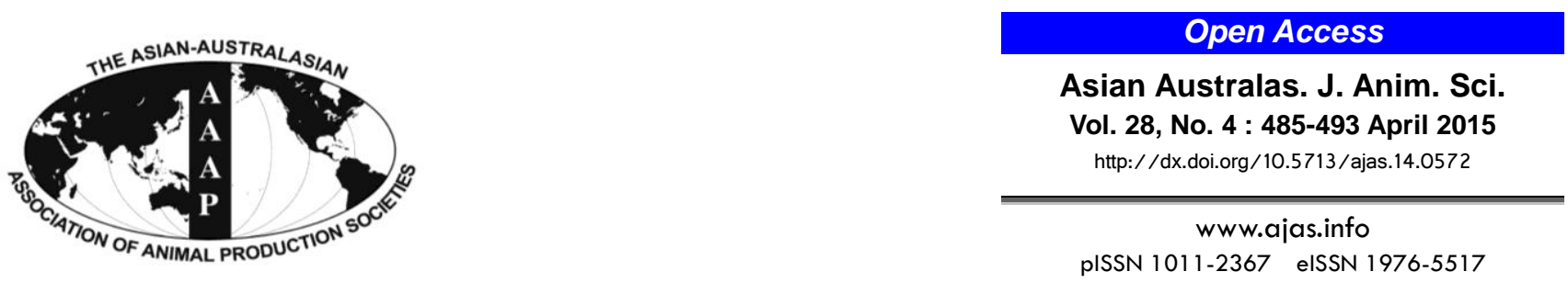

\title{
Rumen Degradability and Post-ruminal Digestion of Dry Matter, Nitrogen and Amino Acids of Three Protein Supplements
}

\author{
Wei Gao, Aodong Chen, Bowen Zhang, Ping Kong, Chenli Liu, and Jie Zhao* \\ College of Animal Science and Technology, Shihezi University, Shihezi 832003, China
}

\begin{abstract}
This study evaluated the in situ ruminal degradability, and subsequent small intestinal digestibility (SID) of dry matter, crude protein (CP), and amino acids (AA) of cottonseed meal (CSM), sunflower seed meal (SFSM) and distillers dried grains with solubles (DDGS) by using the modified three-step in vitro procedure. The ruminal degradability and subsequent SID of AA in rumenundegradable protein (RUP-AA) varied among three protein supplements. The result show that the effective degradability of DM for SFSM, CSM, and DDGS was $60.8 \%, 56.4 \%$, and $41.0 \%$ and their ruminal fermentable organic matter was $60.0 \%, 55.9 \%$, and $39.9 \%$, respectively. The ruminal degradable protein (RDP) content in CP for SFSM, CSM, and DDGS was 68.3\%, 39.0\%, and 32.9\%, respectively, at the ruminal solid passage rate of $1.84 \% / \mathrm{h}$. The SFSM is a good source of RDP for rumen micro-organisms; however, the SID of RUP of SFSM was lower. The DDGS and CSM are good sources of RUP for lambs to digest in the small intestine to complement ruminal microbial AA of growing lambs. Individual RUP-AA from each protein source was selectively removed by the rumen microorganisms, especially for Trp, Arg, His, and Lys ( $<<0.01)$. The SID of individual RUP-AA was different within specific RUP origin ( $\mathrm{p}<0.01$ ). Limiting amino acid was Leu for RUP of CSM and Lys for both RUP of SFSM and DDGS, respectively. Therefore, different protein supplements with specific limitations should be selected and combined carefully in growing lambs ration to optimize AA balance. (Key Words: Ruminal Degradability, Intestinal Digestibility, Protein Supplement, Amino Acids, Lamb)
\end{abstract}

\section{INTRODUCTION}

Modern protein evaluation systems have described the actual protein supply and requirement that is digested and absorbed from the small intestine. Metabolizable protein (MP) available for absorption in the small intestine is dependent on the flow and digestibility of microbial crude protein $(\mathrm{MCP})$ and dietary ruminal undegradable protein (RUP) (NRC, 2001). The application of MP for production purposes requires the evaluation of ruminal MCP production and/or the quantity of RUP present in feeds and their intestinal digestibility of MCP and RUP. Many studies demonstrated that the increased dietary crude protein $(\mathrm{CP})$ levels did not improve the performance of dairy cattle (Chiou et al., 1995; Van Straalen et al., 1997), due to the asynchrony between ruminal degradable protein (RDP) over-supply and fermentable carbohydrate (Chiou et al.,

\footnotetext{
* Corresponding Author: Jie Zhao. Tel: +86-0993-2058077, Fax: +86-0993-2058839, E-mail: zhaojie_xjshz@126.com Submitted Jul. 29, 2014; Revised Sept. 12, 2014; Accepted Oct. 21, 2014
}

1995) or an amino acid (AA) imbalance during absorption (Harstad and Prestløkken, 2001). Comprehensive studies are required for the evaluation of ruminal degradability, intestinal digestibility, AA composition, efficiency of absorption, and utilization of nitrogenous feeds under specific feeding conditions. Several studies demonstrated that MCP has high quality protein (Storm and Ørskov, 1984; Clark et al., 1992) with constant AA composition (Maiga et al., 1996). Although the RUP of various protein feedstuffs is available for cattle, information regarding RUP for lambs is sparse. The objective of this study was to evaluate the ruminal degradability, proportion of RUP, AA composition and intestinal digestibility of cottonseed meal (CSM), sunflower seed meal (SFSM) and distillers dried grains with solubles (DDGS) for formulating lamb-growing diets with optimum balances between rumen energy-nitrogen and intestinal AA.

\section{MATERIALS AND METHODS}

The protocol of the present experiment was approved by

Copyright @ 2015 by Asian-Australasian Journal of Animal Sciences This is an open-access article distributed under the terms of the Creative Commons Attribution Non-Commercial License (http://creativecommons.org/licenses/by-nc/3.0/), which permits unrestricted non-commercial use, distribution, and reproduction in any medium, provided the original work is properly cited. 
the Animal Care and Use Committee, Shihezi University, Shihezi, China.

\section{Animals and diets}

Three Kazakh lambs, weighing $28.0 \pm 2.97 \mathrm{~kg}$, with permanent rumen fistula, were maintained in individual crates $\left(1.4 \times 0.6 \mathrm{~m}^{2}\right)$ at a constant room temperature of $20^{\circ} \mathrm{C}$ under continuous lighting. Animals had free access to fresh water and a mineralized salt block to prevent any deficiency of mineral elements and vitamins. The daily diet was composed of $300 \mathrm{~g}$ (Air-dry basis) of cottonseed hull (4.5\% $\mathrm{CP}, 78.6 \%$ neutral detergent fiber $[\mathrm{NDF}], 58.5 \%$ acid detergent fiber [ADF], DM basis), $300 \mathrm{~g}$ (Air-dry basis) of concentrate supplement $(17 \% \mathrm{CP}$, contained $64.9 \%$ ground corn grain, $3.9 \%$ wheat bran, $20.0 \%$ CSM, $6.4 \%$ soybean meal (SBM), $0.2 \%$ calcium phosphorus, $1.8 \%$ fine ground limestone, $0.8 \%$ salt, $0.5 \%$ sodium bicarbonate, $1.5 \%$ complex premix [Supplied per kg diet: $50 \mathrm{mg}$ of zinc; 80 $\mathrm{mg}$ of iron; $40 \mathrm{mg}$ of manganese; $19 \mathrm{mg}$ of copper; $0.25 \mathrm{mg}$ of cobalt; $0.8 \mathrm{mg}$ of iodine; $0.30 \mathrm{mg}$ of selenium as sodium selenite; 10,000 IU of vitamin A; 600 IU of vitamin $\mathrm{D}_{3} ; 400$ IU of vitamin E]), and wheat straw (5.4\% CP, 75.8\% NDF, 53.5\% ADF, DM basis) was fed ad libitum.

The daily dry matter intake was about $1,200 \mathrm{~g}$ and the diet refusals were collected and weighed daily, and amount of diet offered was adjusted to a minimum of a $10 \%$ refusal rate. The animals were fed twice daily (08:00 and 20:00) in equal parts in 12-hour intervals to maintain a relatively stable rumen environment.

\section{Experimental procedures}

Source of feed samples: Samples of CSM, SFSM, and DDGS were obtained from oil-extraction industries and cornstarch wet mills of the Shida Animal Husbandry Company (Shihezi, Xinjiang). Samples were ground to pass through a $2 \mathrm{~mm}$ sieve and processed for in vitro evaluation.

In situ degradation: In situ ruminal degradability of DM, organic matter $(\mathrm{OM})$ and $\mathrm{CP}$ was determined using the nylon bag technique (Ørskov and McDonald, 1979). The ground samples $(5 \mathrm{~g})$ were placed in nylon bags $\left(5 \times 10 \mathrm{~cm}^{2}\right.$; $40 \mu \mathrm{m}$ pore size), which were subsequently heat-sealed. Each feed sample was incubated in three replicates (one for each time point per lamb) in the rumen. The incubation times were $0,2,4,8,12,18,24,36,48$, and $64 \mathrm{~h}$. The bags were pre-soaked in cold tap water for $15 \mathrm{~min}$ before placement (except $0 \mathrm{~h}$ ) in the ventral sacs of the rumen of the lambs. Then, the bags were removed at the determined time point and placed immediately in cold tap water, coarsely rinsed for about $15 \mathrm{~min}$, and then transferred to the laboratory where they were washed in a fully automatic washing machine (Royalstar, XQB45-421, Hefei, China) with cold water for 15 min under standard program setting. The bags were dried at $55^{\circ} \mathrm{C}$ for $48 \mathrm{~h}$ in a drying oven, then air-equilibrated overnight. The DM content of the residue in each bag was determined at $105^{\circ} \mathrm{C}$ in a forced oven for $2 \mathrm{~h}$.

Intestinal digestibility of RUP: The small-intestinal digestibility (SID) of CP was determined using the modified three-step in vitro procedure suggested by Gargallo et al. (2006) with modification of rumen incubation time for the first step of this procedure. The incubation time (h) of the samples (i.e. $24 \mathrm{~h}$ for CSM, $21 \mathrm{~h}$ for SFSM and $32 \mathrm{~h}$ for DDGS) in rumen was based on the rumen retention time (RRT) calculated from equation (4) stated below, not the traditional $16 \mathrm{~h}$ because we believe that $16 \mathrm{~h}$ was too short for most of the feed as the mean retention time in the rumen of sheep except for SBM. The RRT of SBM was $17 \mathrm{~h}$ calculated from an equation based on the ruminal degradation kinetic estimated for lambs by our group. Other studies (Varvikko and Vanhatalo, 1991; Taghizadeh et al., 2005) also questioned the rationality of pre-incubation time in the rumen of $12 \mathrm{~h}$ for SBM or $16 \mathrm{~h}$ for forage samples and thought that this time interval was probably too short. Whether this time interval is appropriate for protein supplements other than SBM in the rumen of sheep needs further verification.

Five grams of each sample were weighed into 30 nylon bags with 10 bags being incubated in one of the three lambs. Rumen undegradable residuals (RUR) were removed from the bags by cutting off the top of the bags and manually removing the residues. The RURs were composited by the lambs (10 bags for each feed sample) and subsequently ground through a $1 \mathrm{~mm}$ sieve. The DM as well as CP content of the RUR was determined to calculate the DM and $\mathrm{CP}$ degradabilities after rumen incubation. For the subsequent pepsin plus pancreatin digestion trial, a total of 24 bags containing $1.0 \mathrm{~g}$ of RUR of each feed sample were introduced into each incubation bottle which contained $2 \mathrm{~L}$ of a $0.1 \mathrm{~N} \mathrm{HCl}$ solution adjusted to $\mathrm{pH} 1.9$ with $1 \mathrm{~g} / \mathrm{L}$ of pepsin (P-7000, Sigma, St. Louis, MO, USA), and were incubated for $1 \mathrm{~h}$ with a constant-temperature shaker (SHAC, Jintan, China) at $39^{\circ} \mathrm{C}$. After incubation, the bags were rinsed with tap water and introduced into the incubation bottles ( 24 bags per bottle) containing $2 \mathrm{~L}$ of a pancreatin solution $\left(0.5 \mathrm{M} \mathrm{KH}_{2} \mathrm{PO}_{4}\right.$ buffer adjusted to $\mathrm{pH} 7.75$, containing $50 \mathrm{ppm}$ of thymol and $3 \mathrm{~g} / \mathrm{L}$ of P-7545, Sigma, St. Louis, MO, USA), and then further incubated for $24 \mathrm{~h}$ under the same conditions. After incubation, bags were rinsed with tap water until the runoff was clear. The final residues in all bags were analyzed for $\mathrm{DM}, \mathrm{CP}$, and $\mathrm{AA}$ contents by the methods as described below.

\section{Chemical analyses}

The moisture, CP, ether extract (EE), starch and crude ash contents in the test samples (Table 1) were determined according to AOAC official methods as described by procedures 934.01, 976.05, 920.39, 996.11, and 927.02 
(AOAC, 2012). Neutral detergent fibre, ADF, and lignin contents were determined by the method of Van Soest et al. (1991) without sodium sulfite. Heat stable $\alpha$-amylase (A3306, Sigma Chemical Co., St. Louis, MO, USA) was included in the NDF assay ( $10 \mu \mathrm{L}$ per $0.50 \mathrm{~g}$ of sample). Amino acid content of the feeds, rumen undegraded residues and pepsin/pancreatin digestion residues were determined by AA auto-analyzer (Hitachi L8900, Hitachi, Japan) by the method of AOAC (2012). Both acid hydrolysis (to determine all AA except methoinine, cystine and tryptophan) and acid hydrolysis with performic oxidation (to determine methionine and cystine) were carried out. Tryptophan was determined separately by colorimetric method after sodium hydroxide hydrolysis. The contents of non-protein nitrogen, soluble crude protein (SP), neutral detergent insoluble crude protein (NDICP), and acid detergent insoluble crude protein (ADICP) were measured by the method of Licitra et al. (1996). Nonfiber carbohydrate (NFC) was calculated as $100-(\mathrm{CP}+[\mathrm{NDF}-$ NDICP]+EE+ash).

\section{Calculation and statistics}

The DM, OM, and CP degradation data were fitted into the following exponential equation:

$$
\mathrm{D}=\mathrm{a}+\mathrm{b}\left(1-\mathrm{e}^{-\mathrm{ct}}\right)
$$

where $\mathrm{D}$ is the ruminal degradability of nutrients during time $t$, $a$ is the soluble nutrient fraction rapidly washed out of the bags, b is the proportion of insoluble nutrients potentially degradable by microorganisms, $\mathrm{c}$ is the degradation rate of fraction $\mathrm{b}$ per hour (i.e., $\mathrm{Kd}$ ) and $\mathrm{t}$ is the time of incubation.

The in situ effective degradability (ED) of DM, OM, and $\mathrm{CP}$ of each feed sample for each of the three lambs was calculated as follows:

$$
\mathrm{ED}=\mathrm{a}+\mathrm{b} \times[\mathrm{Kd} /(\mathrm{Kd}+\mathrm{Kp})]
$$

where the $1.84 \% \mathrm{~h}^{-1}$ of $\mathrm{Kp}$ predetermined in this experiment was used for the aforementioned calculation.

The ED of OM was also referred to as rumen fermentable organic matter percentage $(\%)$ of the feed, and the ED of CP was also referred to as RDP content in the feed. The RUP of each feed sample was calculated as:

$$
\mathrm{RUP}=100-\mathrm{RDP}(\%)
$$

The RRT of the DM of each feed was calculated according to the equation proposed by Noziere and Michalet-Doreau (2000):

$$
\mathrm{RRT}=(100-\mathrm{a}-\mathrm{b}) / \mathrm{Kp}+\mathrm{b} /(\mathrm{Kd}+\mathrm{Kp})
$$

The fraction of $\mathrm{DM}, \mathrm{OM}$, and $\mathrm{N}$ remaining in the residue at each time point was analyzed statistically by using the non-linear (NLIN) procedure of SAS (SAS, 2003). Observations for $\mathrm{a}$ or $\mathrm{b}$ pool size, $\mathrm{Kd}$, AA contents in original, RUR and final residual, and SID were analyzed by analysis of variance using general linear model of SAS (SAS, 2003). Significance between individual means was identified using the Tukey's multiple range tests (Pearse and Hartley, 1966) and mean differences were considered significant at $\mathrm{p}<0.05$.

\section{RESULTS AND DISCUSSION}

\section{Chemical composition of feed samples}

The chemical compositions of the three protein supplements (Table 1) were similar to NRC (2001) recommendations. Crude protein content for SFSM was the highest, and then CSM, and DDGS was the lowest, but total AA content was the lowest for SFSM when expressed as crude protein percentage. Ether extract, ADF, and NDF content differed markedly among the three products.

\section{In situ dry matter and organic matter kinetic degradation parameters}

The DM, OM, and CP degradabilities in the rumen increased with incubation time (Table 2). During the entire $64 \mathrm{~h}$ incubation time in the rumen, there were significant differences in DM degradabilities among the three protein sources at different time points $(\mathrm{p}<0.01)$. As indicated in Table 2, DM and OM degradabilities of DDGS were significantly lower than those of the other feeds during the

Table 1. Chemical composition (\%) of protein supplements (DM basis $)^{1}$

\begin{tabular}{lccc}
\hline Items & CSM & SFSM & DDGS \\
\hline Dry matter & 88.1 & 90.8 & 92.8 \\
Crude protein & 46.4 & 49.7 & 33.5 \\
Total amino acid & 39.0 & 35.0 & 26.4 \\
Neutral detergent fiber & 28.9 & 40.4 & 30.2 \\
Acid detergent fiber & 21.0 & 34.0 & 15.6 \\
Lignin & 5.1 & 8.2 & 2.3 \\
Soluble crude protein & 13.2 & 33.8 & 2.7 \\
Non-protein nitrogen & 4.9 & 12.1 & 1.5 \\
NDICP & 3.4 & 6.0 & 8.2 \\
ADICP & 1.6 & 3.0 & 4.9 \\
Ether extract & 7.7 & 1.2 & 5.5 \\
NFC & 14.1 & 6.6 & 36.7 \\
Starch & 3.2 & 4.8 & 13.1 \\
Ash & 6.3 & 8.1 & 2.3 \\
\hline
\end{tabular}

DM, dry matter; CSM, cottonseed meal; SFSM, sunflower seed meal; DDGS, distillers dried grains with solubles; NDICP, neutral detergentinsoluble crude protein, ADICP, acid detergent-insoluble crude protein; NFC, nonfiber carbohydrate, EE, ether extract.

${ }^{1}$ Values represent the means of two parallel determinations.

${ }^{2} \mathrm{NFC}=100-[\mathrm{CP}+(\mathrm{NDF}-\mathrm{NDICP})+\mathrm{EE}+\mathrm{ash}]$. 
Table 2. The kinetic ruminal degradability of DM, OM, and CP of the three protein supplements. Each feed sample was incubated in 3 replicates (one for each time point per lamb) in the rumen ${ }^{1}$

\begin{tabular}{|c|c|c|c|c|c|}
\hline Time (h) & CSM & SFSM & DDGS & SEM & p-values \\
\hline \multicolumn{6}{|c|}{ Ruminal degradability of DM } \\
\hline 0 & $24.9^{\mathrm{B}}$ & $27.6^{\mathrm{A}}$ & $11.2^{\mathrm{C}}$ & 0.85 & $<0.001$ \\
\hline 2 & $30.3^{\mathrm{A}}$ & $30.8^{\mathrm{A}}$ & $13.1^{\mathrm{B}}$ & 1.89 & $<0.001$ \\
\hline 4 & $30.8^{\mathrm{A}}$ & $36.9^{\mathrm{A}}$ & $14.9^{\mathrm{B}}$ & 4.04 & $<0.01$ \\
\hline 8 & $37.1^{\mathrm{B}}$ & $43.5^{\mathrm{A}}$ & $16.2^{\mathrm{C}}$ & 1.66 & $<0.001$ \\
\hline 12 & $40.5^{\mathrm{A}}$ & $43.9^{\mathrm{A}}$ & $20.3^{\mathrm{B}}$ & 3.35 & $<0.001$ \\
\hline 18 & $44.8^{\mathrm{A}}$ & $51.5^{\mathrm{A}}$ & $27.2^{\mathrm{B}}$ & 4.76 & $<0.01$ \\
\hline 24 & $45.8^{\mathrm{B}}$ & $56.9^{\mathrm{A}}$ & $30.5^{\mathrm{C}}$ & 3.99 & $<0.001$ \\
\hline 36 & $51.0^{\mathrm{B}}$ & $65.6^{\mathrm{A}}$ & $37.3^{\mathrm{C}}$ & 5.90 & $<0.01$ \\
\hline 48 & $59.6^{\mathrm{A}}$ & $67.6^{\mathrm{A}}$ & $42.5^{\mathrm{B}}$ & 5.22 & $<0.01$ \\
\hline 64 & $65.9^{\mathrm{ab}}$ & $72.5^{\mathrm{a}}$ & $50.2^{\mathrm{b}}$ & 8.03 & $<0.05$ \\
\hline \multicolumn{6}{|c|}{ Ruminal degradability of OM } \\
\hline 0 & $22.6^{\mathrm{B}}$ & $27.1^{\mathrm{A}}$ & $10.6^{\mathrm{C}}$ & 0.84 & $<0.001$ \\
\hline 2 & $30.4^{\mathrm{a}}$ & $30.0^{\mathrm{a}}$ & $12.3^{\mathrm{b}}$ & 6.45 & $<0.05$ \\
\hline 4 & $30.8^{\mathrm{A}}$ & $36.1^{\mathrm{A}}$ & $14.3^{\mathrm{B}}$ & 4.04 & $<0.01$ \\
\hline 8 & $35.9^{\mathrm{B}}$ & $42.2^{\mathrm{A}}$ & $15.6^{\mathrm{C}}$ & 1.50 & $<0.001$ \\
\hline 12 & $39.0^{\mathrm{A}}$ & $42.7^{\mathrm{A}}$ & $19.6^{\mathrm{B}}$ & 3.49 & $<0.001$ \\
\hline 18 & $43.1^{\mathrm{A}}$ & $50.2^{\mathrm{A}}$ & $26.4^{\mathrm{B}}$ & 4.79 & $<0.01$ \\
\hline 24 & $43.8^{\mathrm{B}}$ & $55.8^{\mathrm{A}}$ & $29.7^{\mathrm{C}}$ & 4.06 & $<0.001$ \\
\hline 36 & $49.0^{\mathrm{B}}$ & $64.9^{\mathrm{A}}$ & $36.7^{\mathrm{C}}$ & 6.16 & $<0.01$ \\
\hline 48 & $58.1^{\mathrm{B}}$ & $66.8^{\mathrm{A}}$ & $41.2^{\mathrm{C}}$ & 4.72 & $<0.01$ \\
\hline 64 & $64.6^{\mathrm{ab}}$ & $71.9^{\mathrm{a}}$ & $49.6^{\mathrm{b}}$ & 8.23 & $<0.05$ \\
\hline \multicolumn{6}{|c|}{ Ruminal degradability of $\mathrm{CP}$} \\
\hline 0 & $0.0^{\mathrm{B}}$ & $28.0^{\mathrm{A}}$ & $7.3^{\mathrm{B}}$ & 4.77 & $=0.001$ \\
\hline 2 & $6.9^{\mathrm{B}}$ & $31.1^{\mathrm{A}}$ & $4.7^{\mathrm{B}}$ & 3.23 & $<0.001$ \\
\hline 4 & $8.6^{\mathrm{B}}$ & $38.2^{\mathrm{A}}$ & $9.3^{\mathrm{B}}$ & 5.44 & $<0.001$ \\
\hline 8 & $16.8^{\mathrm{B}}$ & $45.0^{\mathrm{A}}$ & $5.2^{\mathrm{C}}$ & 2.92 & $<0.001$ \\
\hline 12 & $24.8^{\mathrm{B}}$ & $47.7^{\mathrm{A}}$ & $10.9^{\mathrm{C}}$ & 6.09 & $<0.001$ \\
\hline 18 & $26.6^{\mathrm{B}}$ & $55.2^{\mathrm{A}}$ & $14.6^{\mathrm{C}}$ & 3.88 & $<0.001$ \\
\hline 24 & $28.6^{\mathrm{B}}$ & $71.3^{\mathrm{A}}$ & $17.8^{\mathrm{B}}$ & 7.75 & $<0.001$ \\
\hline 36 & $34.9^{\mathrm{B}}$ & $73.7^{\mathrm{A}}$ & $21.3^{\mathrm{B}}$ & 6.90 & $<0.001$ \\
\hline 48 & $52.2^{\mathrm{B}}$ & $75.7^{\mathrm{A}}$ & $30.1^{\mathrm{C}}$ & 6.63 & $<0.001$ \\
\hline 64 & $56.3^{\mathrm{B}}$ & $82.8^{\mathrm{A}}$ & $35.4^{\mathrm{C}}$ & 9.39 & $<0.01$ \\
\hline
\end{tabular}

DM, dry matter; OM, organic matter; CP, crude protein; CSM, cottonseed meal; SFSM, sunflower seed meal; DDGS, distillers dried grains with solubles; SEM, standard error of the mean.

a,b,c Within rows, means with different superscripts differ $(\mathrm{p}<0.05)$.

${ }^{A, B, C}$ Within rows, means with different superscripts differ $(p<0.01)$.

entire $64 \mathrm{~h}$ incubation period $(\mathrm{p}<0.01)$. The ruminal degradabilities of DM and OM in DDGS at $64 \mathrm{~h}$ accounted for nearly one half of the original sample (i.e. $50.2 \%$ and $49.6 \%$, respectively), which strongly indicated that most of the soluble protein fractions in DDGS had been removed during processing and resulted in a very insoluble, ruminally undegradable protein that contained mostly prolamins and glutelins (Clark et al., 1987). The DM and OM degradabilities of SFSM were significantly higher than those of CSM at $8 \mathrm{~h}, 24 \mathrm{~h}$, and $36 \mathrm{~h}$ for both DM and OM $(\mathrm{p}<0.01)$ and $\mathrm{OM}$ at $48 \mathrm{~h}(\mathrm{p}<0.01)$. The final degradability of DM and OM in SFSM amounted to $72.5 \%$ and $71.9 \%$, respectively.

The water solubility (i.e. a value) of DM for SFSM and CSM was similar, and both of them were significantly greater than that of DDGS $(\mathrm{p}<0.01)$. The a values of SFSM and CSM were similar to the value reported previously (Kamalak et al., 2005), but the value of DDGS was relatively lower compared with the value reported by Clark et al. (1987). The potentially degradable fractions (b) of the three protein supplements were similar $(\mathrm{p}>0.05)$. However the contents of fractions of $b$ were higher in SFSM and CSM than findings of Kamalak et al. (2005). Similar to our findings, Kamalak et al. (2005) reported the fractions of $b$ were not different between SFSM, CSM, and DDGS. The Kd of DM for SFSM was higher $(p<0.01)$ than that of CSM and DDGS.

\section{In situ crude protein kinetic degradation parameters}

During the whole incubation period, the ruminal degradation of SFSM was the highest, with CSM being the intermediate, and DDGS the lowest $(\mathrm{p}<0.01)$. The CP degradability of CSM was higher than that of DDGS except at 2, 4, 24, and $36 \mathrm{~h}$ incubation $(\mathrm{p}<0.01)$.

In spite of the higher NDF content, CP in SFSM exhibited greater water solubility $(27.44 \%)$ than the other protein sources $(p<0.01)$, and there were no significant difference between water solubilities of CP in DDGS and in CSM ( $>>0.05$ ) (Table 3 ). The content of soluble protein in CSM was lower than the value reported in an earlier study (Clark et al., 1987). The disparity between results from different labs indicated that there was not only a variation in the soluble fraction of CP in CSM, but also a low repeatability of the technique. The $\mathrm{Kd}$ values of $\mathrm{CP}$ were variable between the different feed samples, but SFSM had a faster rate of degradation $(4.3 \% / \mathrm{h})$ compared with other feeds whose $\mathrm{Kd}$ value ranged from $2.0 \% / \mathrm{h}$ for DDGS to $2.9 \% / \mathrm{h}$ for CSM. The subsequent ED of CP was the lowest for DDGS (32.9\%), intermediate for CSM (39.0) and highest for SFSM $(68.3 \%)$ (Table 3). The value of SFSM estimated in this study was consistent with the result of Economides (1998) indicating that ruminal degradability of sunflower meal protein is often $>60 \%$, but the value of CSM estimated in this study was lower than that of Kamalak et al. (2005). Estimated RUP percentage in this study was slightly higher than the mean values recommended by NRC (1989) for both CSM (41\%) and SFSM (26\%). The content of RUP in CP in DDGS was $67.1 \%$, much higher than the value of Kelzer et al. (2010) for DDGS produced with a traditional dry milling process, but within the range of $59.1 \%$ to $71.7 \%$ reported by Kleinschmit et al. (2007). The higher RUP in DDGS may be attributed to heat-damaged protein as indicated by its low SP content $(2.7 \%)$ and high ADICP content (4.9\%). 
Table 3. In situ ruminal degradability parameters of DM, OM, and CP of the three protein supplements ${ }^{1}$

\begin{tabular}{|c|c|c|c|c|c|}
\hline Items $^{2}$ & CSM & SFSM & DDGS & SEM & p-values \\
\hline \multicolumn{6}{|c|}{ DM degradation parameters } \\
\hline $\mathrm{a}(\%)^{2}$ & $27.4^{\mathrm{A}}$ & $28.3^{\mathrm{A}}$ & $11.3^{\mathrm{B}}$ & 1.86 & $<0.001$ \\
\hline $\mathrm{b}(\%)^{2}$ & 55.0 & 48.0 & 68.3 & 17.23 & 0.398 \\
\hline $\mathrm{kd}(\% / \mathrm{h})^{2}$ & $2.1^{\mathrm{B}}$ & $3.9^{\mathrm{A}}$ & $1.4^{\mathrm{B}}$ & 0.60 & 0.006 \\
\hline $\mathrm{ED}(\%)$ & 56.4 & 60.8 & 41.0 & - & - \\
\hline RRT ( h) & 23.7 & 21.3 & 32.1 & - & - \\
\hline \multicolumn{6}{|c|}{ OM degradation parameters } \\
\hline $\mathrm{a}(\%)^{2}$ & $26.7^{\mathrm{A}}$ & $27.7^{\mathrm{A}}$ & $10.3^{\mathrm{B}}$ & 1.97 & $<0.001$ \\
\hline $\mathrm{b}(\%)^{2}$ & 59.2 & 48.7 & 67.4 & 17.92 & 0.484 \\
\hline $\mathrm{Kd}(\% / \mathrm{h})^{2}$ & $1.8^{\mathrm{B}}$ & $3.6^{\mathrm{A}}$ & $1.3^{\mathrm{B}}$ & 0.54 & 0.004 \\
\hline FOM $(\%)$ & 55.9 & 60.0 & 39.9 & - & \\
\hline $\mathrm{RENB}^{3}$ & -87.2 & -225.6 & -42.6 & - & \\
\hline \multicolumn{6}{|c|}{$\mathrm{CP}$ degradation parameters } \\
\hline $\mathrm{a}(\% \mathrm{CP})^{2}$ & $3.4^{\mathrm{B}}$ & $27.4^{\mathrm{A}}$ & $8.3^{\mathrm{B}}$ & 2.589 & $<0.001$ \\
\hline $\mathrm{b}(\% \mathrm{CP})^{2}$ & 58.5 & 58.6 & 47.7 & 11.11 & 0.439 \\
\hline $\mathrm{Kd}(\% / \mathrm{h})^{2}$ & $2.9^{\mathrm{ab}}$ & $4.3^{\mathrm{a}}$ & $2.0^{\mathrm{b}}$ & 0.75 & 0.027 \\
\hline $\mathrm{RDP}(\%)$ & 39.0 & 68.3 & 32.9 & - & - \\
\hline RUP (\%) & 61.0 & 31.7 & 67.1 & - & - \\
\hline
\end{tabular}

DM, dry matter; OM, organic matter; CP, crude protein; CSM, cottonseed meal; SFSM, sunflower seed meal; DDGS, distillers dried grains with solubles; SEM, standard error of the mean; ED, effective degradability; RRT, rumen retention time; FOM, fermentable organic matter in rumen; RENB, rumen energy nitrogen balance; RDP, rumen-degradable protein; RUP, rumen-undegradable protein; SD, standard deviation; MCP, microbial crude protein.

${ }^{1}$ Values of $\mathrm{a}, \mathrm{b}$ and $\mathrm{Kd}$ in the table represent the mean $\pm \mathrm{SD}$ of three lambs. Within rows, means with different uppercase letter significant differ $(\mathrm{p}<0.01)$, with lowercase letter superscript means differ $(\mathrm{p}<0.05)$.

${ }^{2}$ a, the soluble nutrient fraction rapidly washed out of the bags; b, the proportion of insoluble nutrients potentially degradable by microorganisms, Kd, the degradation rate of fraction $b$ per hour.

${ }^{3}$ Equals to the difference of MCP production predicted from the amount of FOM minus the quantity of MCP predicted from the amount of RDP provided by each feedstuff. The conversion co-efficiency of FOM per kg was assumed to be $145 \mathrm{~g}$ of MCP, whereas the conversion ratio of RDP was adopted as 0.9 (Jarrige, 1989).

\section{Intestinal digestibility of rumen-undegradable protein}

The ruminal DM degradability of CSM and DDGS was significantly higher than that of SFSM $(\mathrm{p}<0.01)$, but no statistical difference was observed between CSM and DDGS ( $>>0.05$ ) (Table 4). The relatively lower ruminal DM degradability of SFSM may be accounted for by the higher content of NDF in SFSM. The ruminal CP degradability of DDGS was significantly higher than that of CSM $(p<0.05)$, but no significant difference existed between DDGS and
SFSM ( $p>0.05$ ). The relatively higher ruminal degradability of DDGS might be related to its longer incubation time in the rumen compared to that of CSM.

The intestinal DM digestibilities of RUR from the three proteinaceous feeds were significantly different $(p<0.01)$ with CSM being the highest, SFSM being the lowest, and DDGS being in the middle (Table 4). On the other hand, the intestinal CP digestibility of DDGS was the highest and that of SFSM was the lowest, with CSM in the middle $(\mathrm{p}<0.01)$.

Table 4. Ruminal degradation and intestinal digestibility of DM and CP in RUR determined by the in situ nylon bag technique and a modified in vitro three-step procedure ${ }^{1}$

\begin{tabular}{|c|c|c|c|c|c|}
\hline Items & CSM & SFSM & DDGS & SEM & p-values \\
\hline \multicolumn{6}{|c|}{ Rumen degradation $^{2}$} \\
\hline $\mathrm{DM}(\%)$ & $29.8^{\mathrm{A}}$ & $17.0^{\mathrm{B}}$ & $27.4^{\mathrm{A}}$ & 5.14 & $<0.001$ \\
\hline $\mathrm{CP}(\%)$ & $12.4^{\mathrm{b}}$ & $12.9^{\mathrm{ab}}$ & $15.3^{\mathrm{a}}$ & 4.41 & 0.051 \\
\hline \multicolumn{6}{|c|}{ Intestinal digestibility $^{3}$} \\
\hline $\mathrm{DM}(\%)$ & $64.3^{\mathrm{A}}$ & $58.8^{\mathrm{C}}$ & $62.2^{\mathrm{B}}$ & 3.26 & $<0.001$ \\
\hline $\mathrm{CP}(\%)$ & $89.1^{\mathrm{B}}$ & $88.5^{\mathrm{C}}$ & $93.3^{\mathrm{A}}$ & 0.79 & $<0.001$ \\
\hline
\end{tabular}

DM, dry matter; CP, crude protein; RUR, rumen undegradable residuals; CSM, cottonseed meal; SFSM, sunflower seed meal; DDGS, distillers dried grains with solubles; SEM, standard error of the mean; RRT, rumen retention time; RUP, rumen-undegradable protein.

${ }^{1}$ Mean values within the same row with different uppercase superscript means significant difference $(\mathrm{p}<0.01)$, while means with different lowercase letters means difference $(\mathrm{p}<0.05)$.

${ }^{2}$ The rumen incubation time of each protein feed (i.e. $24 \mathrm{~h}$ for CSM, $21 \mathrm{~h}$ for SFSM and $32 \mathrm{~h}$ for DDGS, respectively) was calculated according to the equation RRT $=(100-a-b) / K p+b /(K d+K p)$ illustrated in the section of intestinal digestion of RUP in the paper.

${ }^{3}$ The intestinal digestibility observations were expressed as the percentages of the RUR. 
The digestibility of DDGS was slightly higher than the NRC (2001) recommendation, i.e., 80, but that of CSM and SFSM was closer to the recommended values by NRC (2001). Similarly, several studies have also reported that the RUP digestibility estimates for DDGS vary considerably, ranging from $60 \%$ to $90 \%$ (Masoero et al., 1994; O'Mara et al., 1997; Kleinschmit et al., 2007; Kononoff et al., 2007). The digestible RUP in DDGS estimated by in vitro threestep procedure in this study $(93.3 \%)$ was similar to the value $(91.9 \%)$ for DDGS produced with a traditional dry milling process estimated with a mobile nylon bag technique (Kelzer et al., 2010). Additionally, the results from the three-step procedure for SBM, corn gluten meal, fish meal and meat and bone meal were identical with the values obtained using the mobile-bag technique (de Boer et al., 1987), but were greater than the actual digestion estimated in vivo (Titgemeyer et al., 1989). The discrepancy between the in vivo and in vitro three-step procedure estimates may partly be due to the protein digested and absorbed in the abomasum; thus, less digestible dietary protein reaches the small intestines (Calsamiglia and Stern, 1995). Another cause of discrepancy between the in vivo and in vitro three-step procedure might be the incubation time in the rumen. Numerous studies have chosen the incubation time of $16 \mathrm{~h}$ in the rumen in the "standard" in vitro three-step procedure to determine RUP digestibility of SBM (Boucher et al., 2009a, b). However, most of feedstuffs had retention times longer than $20 \mathrm{~h}$ in this study, and DDGS even exceeded $32 \mathrm{~h}$ estimated on lambs, except for SBM where the RRT was close to the typical $16 \mathrm{~h}$.
Therefore, it is arbitrary and not in accordance with reality to fix the rumen incubation time to $16 \mathrm{~h}$ for all feeds. Further experiments will be needed to verify the appropriate incubation time in the rumen for the in vitro three-step procedure on lambs.

\section{Amino acid degradability and subsequent intestinal digestibility}

On a DM basis, RURs of the three tested protein supplements contained more CP (e.g. CP contents in RURs for CSM, SFSM, and DDGS were $63.7 \%, 52.2 \%$, and $39.1 \%$, respectively). Therefore, the contents of most AA in RURs from the supplements were significantly higher than their original sources $(p<0.01)$, except for Arg, Trp, Cys, and Pro in RUR from CSM, and Trp in RURs from SFSM and DDGS, which were significantly lower than its original source $(\mathrm{p}<0.01)$ (Table 5). In contrast, some AA contents such as Arg, His, Lys, Cys, Glu, Gly and Pro in RUP for SFSM as well as Arg, Cys and Pro in RUP for DDGS remained unchanged after rumen incubation $(p>0.05)$. Some earlier studies (Varvikko et al., 1983; Weakley et al., 1983) reported that the AA profiles of the RUPs for protein supplements closely resembled those of the original sources. However, other later studies (Crooker et al., 1986; Cozzi and Polan, 1994) discovered more variations in the AA profiles between RUPs and their origins. Although microbial AA contamination might be a cause of the variation in AA profiles, the AA profiles of original feeds and of their RUPs were different. The main reason for such difference was the concentrated $\mathrm{CP}$ and AA contents in

Table 5. Profiles of AA of original protein supplements (ORI), rumen undegradable residue (RUR) and small intestinal digestibility (SID) determined by the modified in vitro three-step procedure ${ }^{1}$

\begin{tabular}{|c|c|c|c|c|c|c|c|c|c|c|c|c|c|c|c|c|c|c|c|c|}
\hline Items & Arg & His & Ile & Leu & Lys & Met & Phe & Thr & Trp & Val & TEAA & Ala & Asp & Cys & Glu & Gly & Pro & Ser & Tyr & TNEAA \\
\hline \multicolumn{21}{|l|}{$\overline{\mathrm{CSM}}$} \\
\hline $\begin{array}{l}\text { ORI } \\
(\% \mathrm{CP})\end{array}$ & 11.1 & 2.8 & 3.0 & 5.5 & 3.8 & 0.8 & 4.9 & 2.9 & 1.6 & 4.1 & 40.5 & 3.6 & 8.0 & 0.9 & 17.7 & 3.9 & 3.5 & 3.8 & 2.2 & 43.5 \\
\hline $\begin{array}{l}\text { RUR }^{2} \\
(\% \mathrm{CP})\end{array}$ & $8.9^{* *}$ & 2.9 & $3.4 * *$ & $5.9^{* *}$ & 3.8 & $1.1^{*}$ & 5.0 & 3.0 & $0.4^{* *}$ & $4.5^{*}$ & $43.9^{* *}$ & $3.9^{*}$ & $8.2 * *$ & $0.4 * *$ & 16.6 & 3.8 & $3.4 * *$ & 3.5 & 2.3 & $42.0^{* *}$ \\
\hline $\begin{array}{r}\operatorname{SID}^{3} \\
(\%)\end{array}$ & $92.0^{\mathrm{A}}$ & $88.5^{\mathrm{BC}}$ & $85.4^{\mathrm{DEF}}$ & $85.1^{\mathrm{DEF}}$ & $81.4^{\mathrm{G}}$ & $83.8^{\mathrm{FG}}$ & $88.8^{\mathrm{BC}}$ & $85.0^{\mathrm{DEF}}$ & $75.4^{\mathrm{H}}$ & $86.6^{\mathrm{CDEF}}$ & $87.1^{\mathrm{CDE}}$ & $85.3^{\text {DEF }}$ & $89.1^{\mathrm{ABC}}$ & $78.1^{\mathrm{H}}$ & $91.2^{\mathrm{AB}}$ & $84.3^{\mathrm{EFG}}$ & $83.9^{\mathrm{FG}}$ & $87.1^{\mathrm{CDE}}$ & $87.7^{\mathrm{CD}}$ & $87.3^{\mathrm{CDE}}$ \\
\hline \multicolumn{21}{|l|}{ SFSM } \\
\hline $\begin{array}{l}\text { ORI } \\
(\% \mathrm{CP})\end{array}$ & 4.2 & 2.8 & 3.3 & 6.0 & 3.2 & 0.8 & 3.2 & 3.5 & 0.6 & 4.2 & 31.9 & 3.5 & 5.8 & 0.5 & 14.5 & 4.1 & 4.8 & 3.5 & 2.0 & 38.5 \\
\hline $\begin{array}{l}\text { RUR }^{2} \\
(\% \mathrm{CP})\end{array}$ & 4.4 & 2.9 & $3.7 * *$ & $6.4 * *$ & 3.2 & $0.9^{*}$ & $3.4^{*}$ & $3.9^{* * *}$ & $0.6^{* *}$ & $4.6^{* * *}$ & $34.0^{* *}$ & $3.9^{* *}$ & $6.3 * *$ & 0.7 & 14.2 & 4.2 & 4.9 & $3.7^{*}$ & $2.2 *$ & $40.1^{* *}$ \\
\hline $\begin{array}{r}\operatorname{SID}^{3} \\
(\%)\end{array}$ & $91.7^{\mathrm{AB}}$ & $92.0^{\mathrm{AB}}$ & $89.2^{\mathrm{BCD}}$ & $91.3^{\mathrm{ABC}}$ & $87.2^{\mathrm{DE}}$ & $89.9^{\mathrm{BCD}}$ & $89.7^{\mathrm{BCD}}$ & $87.1^{\mathrm{DE}}$ & $87.6^{\mathrm{DE}}$ & $88.5^{\mathrm{CDE}}$ & $89.7^{\mathrm{BCD}}$ & $91.6^{\mathrm{AB}}$ & $91.3^{\mathrm{ABC}}$ & $83.5^{\mathrm{F}}$ & $93.7^{\mathrm{A}}$ & $89.4^{\mathrm{BCD}}$ & $85.8^{\mathrm{EF}}$ & $88.1^{\mathrm{DE}}$ & $86.2^{\mathrm{EF}}$ & $89.2^{\mathrm{BCD}}$ \\
\hline \multicolumn{21}{|l|}{ DDGS } \\
\hline $\begin{array}{l}\text { ORI } \\
(\% \mathrm{CP})\end{array}$ & 3.5 & 2.7 & 3.2 & 10.6 & 2.4 & 1.1 & 4.3 & 3.2 & 0.3 & 4.1 & 35.4 & 6.1 & 5.5 & 0.6 & 14.9 & 3.2 & 6.9 & 3.8 & 2.7 & 43.7 \\
\hline $\begin{array}{l}\text { RUR }^{2} \\
(\% \mathrm{CP})\end{array}$ & 3.5 & $3.3 * *$ & $3.8 * *$ & $12.9^{* *}$ & $2.8^{* *}$ & $1.5^{* * *}$ & $5.1 * *$ & $3.8^{*}$ & $0.2^{* *}$ & $4.7 * *$ & $41.5^{* *}$ & $7.5^{* *}$ & $6.7 * *$ & 0.7 & $18.3^{* *}$ & $3.6^{* *}$ & 7.3 & $4.7 * *$ & $3.5^{* *}$ & $52.3 * *$ \\
\hline $\begin{array}{r}\operatorname{SID}^{3} \\
(\%)\end{array}$ & $93.9^{\mathrm{BC}}$ & $94.8^{\mathrm{AB}}$ & $95.3^{\mathrm{AB}}$ & $96.5^{\mathrm{A}}$ & $93.2^{\mathrm{C}}$ & $95.9^{\mathrm{A}}$ & $95.8^{\mathrm{A}}$ & $92.5^{\mathrm{CD}}$ & $88.4^{\mathrm{E}}$ & $95.1^{\mathrm{AB}}$ & $95.2^{\mathrm{AB}}$ & $96.0^{\mathrm{A}}$ & $95.1^{\mathrm{AB}}$ & $82.5^{\mathrm{F}}$ & $96.5^{\mathrm{A}}$ & $91.2^{\mathrm{D}}$ & $95.3^{\mathrm{AB}}$ & $95.0^{\mathrm{AB}}$ & $94.9^{\mathrm{AB}}$ & $94.9^{\mathrm{AB}}$ \\
\hline
\end{tabular}

AA, amino acids; TEAA, total of essential amino acid; TNEAA, total of non-essential amino acid; CSM, cottonseed meal; SFSM, sunflower seed meal; DDGS, distillers dried grains with solubles; $\mathrm{CP}$, crude protein; DM, dry matter.

${ }^{1}$ Amino acids as a percentage of $\mathrm{CP}$ on a DM basis.

${ }^{2}$ Mean values with double * superscript means there were significant difference $(\mathrm{p}<0.01)$ compared with its AA profile in original feed, while means with single * means difference $(\mathrm{p}<0.05)$.

${ }^{3}$ Mean values within the same row with different uppercase letter superscript means significant difference $(\mathrm{p}<0.01)$. 
RURs after rumen exposure, not the microbial AA contamination. Although the complete chemical composition for RUR of intact feed was not analysed owing to the limited amount left in the bag in this study, studies of Boucher et al. (2009a, b) demonstrated that the concentration of NFC and starch in the RURs of SBM, SoyPlus and DDGS decreased markedly after $16 \mathrm{~h}$ incubation in the rumen of cow. Two factors can contribute to the difference in the AA profile of the RUR compared with the feed: i) AA are not degraded at the same rate in the rumen, and ii) microbial contamination of the RUR can result in a different AA profile of feeds after ruminal incubation (Boucher et al., 2009a).

The individual AA degradability after rumen exposure among three protein sources was significantly different $(p<0.01)$. The descending order of rumen degradability of essential amino acid (EAA) for CSM was Trp $>$ Arg $>$ Lys $>$ Phe $>$ Val, and non-essential amino acid (NEAA) for CSM was Cys $>$ Ser $>$ Tyr $>$ Glu $>$ Pro; the grading down sequence of EAA for SFSM was Trp $>$ Lys $>$ Phe $>$ Val $>$ His and Arg and NEAA for SFSM was Ser $>$ Glu $>$ Tyr $>$ Pro $>$ Gly; the same descending sequence of EAA degradation for DDGS was Trp>Arg>Val $>$ Lys $>$ Phe, and the first four NEAA for DDGS was Cys $>$ Pro $>$ Gly $>$ Ser. These results indicated that Trp in these protein supplements was actively degraded by rumen micro-organisms of sheep. In addition to Trp, the basic AA (Arg, His, and Lys), Val and Phe in the three protein supplements were also preferentially degraded by microbes, though the preferential order was different among them. These results further support the concept that individual AA in different protein sources are selectively removed by the rumen micro-organisms, especially for Trp, Arg, His, and Lys. Different rates of degradation for individual AA modified the AA profiles in the RUP relative to the original sources (Cozzi et al., 1995).

These results also indicated that the SID of each AA within a specific protein feed was significantly different ( $<<0.01$ ). The SID of Cys and Trp was the lowest for the three RUPs, probably owing to the fact that large amount of these AA had been degraded in the rumen before entering the small intestine compared with other AAs (Table 5). The SID of Lys in the three RUPs and also Met in RUP of CSM origin were significantly lower than the other EAAs ( $\mathrm{p}<0.01$ ). Arginine, Asp, Glu in CSM, Arg, His, Leu, Ala, Asp, Glu in SFSM, and all AA except for Trp and Cys in DDGS had a relatively higher SID compared with the others (Table 5). Thus, it can be said that these AA largely accounted for the difference between the SID of EAA and NEAA. The intestinal digestibility coefficients of Arg for the test RURs were the highest. A similar result was also reported by Taghizadeh et al. (2005), but the result for Gly in our study was different to theirs. The high digestibility of Arg could be the result of the action of trypsin (EC
3.4.21.4), an endopeptidase that hydrolyzes only Lys and Arg bonds (Taghizadeh et al., 2005).

Apparent rankings of limiting EAA relative to whole body protein of sheep (MacRae et al., 1993) were, respectively, Met, Lys, and Thr for CSM; Met, Lys and Arg for SFSM; Lys, Arg, and Met for DDGS. After ruminal incubation, RUP from CSM had totally different ranking of limiting EAA from its origin. The first-, second- and thirdlimiting EAA changed to Leu, Ile and His. The first- and second limiting EAA for SFSM exchanged their ranking after ruminal degradation, but the third-limiting EAA was still the same. In contrast, the first- and second-limiting EAA of RUP from DDGS had the same ranking as its original source, but the third-limiting EAA changed to Thr. These findings indicate that the AA profile of the RUP might differ from that of original source. Cys might be the potential limiting AA for protein accretion in growing lamb based on the calculated ranking score relative to whole body protein of sheep. One possible reason is that the degradation rate of Cys in the rumen was very high compared with other AA $(\mathrm{p}<0.01)$; another reason might be that the hydrolytic analytic method of sulphur containing AA such as Met and Cys, may not be recovered 100\% in laboratory analysis (Cozzi and Polan, 1994). Cys accounts for about $10 \%$ of the AAs in wool protein compared with $1.3 \%$ in the whole body (MacRae et al., 1993). If it were considered to be a dietary EAA, Cys would rank firstlimiting in RUP of CSM, third-limiting in RUPs of SFSM and DDGS, respectively.

\section{IMPLICATIONS}

In summary, the rumen degradability of CP and AA and subsequent intestinal digestibility of RUP and AA varied among the three protein supplements for growing lambs. SFSM is a very good source of RDP for rumen microorganisms to utilize; however, the protein digestion rate of the RUP from SFSM is lower. In growing lambs, DDGS and CSM are good sources of RUP to be digested and absorbed in the small intestines to complement ruminal microbial AA. Individual AA from each protein source was selectively removed by the rumen micro-organisms, especially Trp, Arg, His, and Lys. The intestinal digestibility of individual RUP-AA was different within specific RUP origin. Specific first-limiting AA might be Leu for RUP of CSM, Lys for both RUP of SFSM and DDGS, respectively. Therefore, different protein supplements with specific limitations should be selected and combined carefully in the growing lambs ration to optimize AA balance.

\section{ACKNOWLEDGMENTS}

This work was financially supported by the National 
Science Foundation of China (31260557); Doctors Special Fund of Xinjiang Production and Construction Corps (2013BB018). The authors would like to thank Mrs Fengming Li and Dr. Hao Li for their technical support for the ruminal and small intestinal fistula surgery.

\section{REFERENCES}

AOAC. 2012. Official Methods of Analysis. 17th edn. Association of Official Analytical Chemists, Arlington, VA, USA.

Boucher, S. E., S. Calsamiglia, C. M. Parsons, H. H. Stein, M. D. Stern, P. S. Erickson, P. L. Utterback, and C. G. Schwab. 2009a. Intestinal digestibility of amino acids in rumen undegradable protein estimated using a precision-fed cecectomized rooster bioassay: 1. Soybean meal and SoyPlus. J. Dairy Sci. 92: 4489-4498.

Boucher, S. E., S. Calsamiglia, C. M. Parsons, H. H. Stein, M. D. Stern, P. S. Erickson, P. L. Utterback, and C. G. Schwab. 2009b. Intestinal digestibility of amino acids in rumen-undegraded protein estimated using a precision-fed cecectomized rooster bioassay: 2. Distillers dried grains with solubles and fish meal. J. Dairy Sci. 92:6056-6067.

Calsamiglia, S. and M. D. Stern. 1995. A three-step in vitro procedure for estimating intestinal digestion of protein in ruminants. J. Anim. Sci. 73:1459-1465.

Chiou, P. W. S., K. Chen, K. Kuo, J. Hsu, and B. Yu. 1995. Studies on the protein degradabilities of feedstuffs in Taiwan. Anim. Feed Sci. Technol. 55:215-226.

Clark, J. H., M. R. Murphy, and B. A. Crooker. 1987. Supplying the protein needs of dairy cattle from by-product feeds. J. Dairy Sci. 70:1092-1109.

Clark, J. H., T. H. Klusmeyer, and M. R. Cameron. 1992. Microbial protein synthesis and flows of nitrogen fractions to the duodenum of dairy cows. J. Dairy Sci. 75:2304-2323.

Cozzi, G. and C. E. Polan. 1994. Corn gluten meal or dried brewers grains as partial replacement for soybean meal in the diet of Holstein cows. J. Dairy Sci. 77:825-834.

Cozzi, G., I. Andrighetto, P. Berzaghi, and C. E. Polan. 1995. In situ ruminal disappearance of essential amino acids in protein feedstuffs. J. Dairy Sci. 78:161-171.

Crooker, B. A., J. H. Clark, R. D. Shanks, and E. E. Hatfield. 1986. Effects of ruminal exposure on the amino acid profile of heated and formaldehyde-treated soybean meal. J. Dairy Sci. 69:2648-2657.

de Boer, G., J. J. Murphy, and J. J. Kennelly. 1987. Mobile nylon bag for estimating intestinal availability of rumen undegradable protein. J. Dairy Sci. 70:977-982.

Economides, S. 1998. The nutritive value of sunflower meal and its effect on replacing cereal straw in the diets of lactating ewes and goats. Lives. Prod. Sci. 55:89-97.

Gargallo, S., S. Calsamiglia, and A. Ferret. 2006. Technical note: A modified three-step in vitro procedure to determine intestinal digestion of proteins. J. Anim. Sci. 84:2163-2167.

Harstad, O. M. and E. Prestløkken. 2001. Rumen degradability and intestinal indigestibility of individual amino acids in corn gluten meal, canola meal and fish meal determined in situ. Anim. Feed Sci. Technol. 94:127-135.

Jarrige, R. 1989. Ruminant Nutrition: Recommended Allowances and Feed Tables. John Libbey Eurotext, London, England.
Kamalak, A., O. Canbolat, Y. Gurbuz, and O. Ozay. 2005. In situ ruminal dry matter and crude protein degradability of plantand animal-derived protein sources in Southern Turkey. Small Rumin. Res. 58:135-141.

Kelzer, J. M., P. J. Kononoff, L. O. Tedeschi, T. C. Jenkins, K. Karges, and M. L. Gibson. 2010. Evaluation of protein fractionation and ruminal and intestinal digestibility of corn milling co-products. J. Dairy Sci. 93:2803-2815.

Kleinschmit, D. H., J. L. Anderson, D. J. Schingoethe, K. F. Kalscheur, and A. R. Hippen. 2007. Ruminal and intestinal degradability of distillers grains plus solubles varies by source. J. Dairy Sci. 90:2909-2918.

Kononoff, P. J., S. K. Ivan, and T. J. Klopfenstein. 2007. Estimation of the proportion of feed protein digested in the small intestine of cattle consuming wet corn gluten feed. J. Dairy Sci. 90:2377-2385.

Licitra, G., T. M. Hernandez, and P. J. Van Soest. 1996. Standardization of procedures for nitrogen fractionation of ruminant feeds. Anim. Feed Sci. Technol. 57:347-358.

MacRae, J. C., A. Walker, D. Brown, and G. E. Lobley. 1993. Accretion of total protein and individual amino acids by organs and tissues of growing lambs and the ability of nitrogen balance techniques to quantitate protein retention. Anim. Sci. 57:237-245.

Maiga, H. A., J. D. J. Schingoethe, and J. E. Henson. 1996. Ruminal degradation, amino acid composition, and intestinal digestibility of the residual components of five protein supplements. J. Dairy Sci. 79:1647-1653.

Masoero, F., L. Fiorentini, F. Rossi, and A. Piva. 1994. Determination of nitrogen intestinal digestibility in ruminants. Anim. Feed Sci. Technol. 48: 253-263.

National Research Council. 1989. Nutrient Requirements of Dairy Cattle. 6th Ed. National Academic Press, Washington, DC, USA.

National Research Council. 2001. Nutrient Requirements of Dairy Cattle. 7th Ed. National Academic Press, Washington, DC, USA.

Noziere, P. and B. Michalet-Doreau. 2000. In sacco methods. In: Farm Animal Metabolism and Nutrition (Ed. J. F. F. D'Mello). CABI Publishing, Wallingford, UK. pp. 233-253.

O’Mara, F. P., J. J. Murphy, and M. Rath. 1997. The amino acid composition of protein feedstuffs before and after ruminal incubation and after subsequent passage through the intestines of dairy cows. J. Anim. Sci. 75:1941-1949.

Ørskov, E. R. and I. McDonald. 1979. The estimation of protein degradability in the rumen from incubation measurements weighted according to rate of passage. J. Agric. Sci. Camb. 92: 499-503.

Pearse, E. S. and H. O. Hartley. 1966. Biometrika Tables for Statisticians, vol. 1. Cambridge University Press, London, UK.

SAS Institute Inc. 2003. SAS/STAT User's Guide: Version 9. 7th edn. SAS Instute Inc., Cary, NC, USA.

Storm, E. and E. R. Ørskov. 1984. The nutritive value of rumen micro-organisms in ruminants. 4. The limiting amino acids of microbial protein in growing sheep determined by a new approach. Br. J. Nutr. 52:613-620.

Taghizadeh, A., M. Danesh Mesgaran, R. Valizadeh, F. Eftekhar Shahroodi, and K. Stanford. 2005. Digestion of feed amino acids in the rumen and intestine of steers measured using a mobile nylon bag technique. J. Dairy Sci. 88:1807-1814. 
Titgemeyer, E. C., N. R. Merchen, and L. L. Berger. 1989. Evaluation of soybean meal, corn gluten meal, blood meal and fish meal as sources of nitrogen and amino acids disappearing from the small intestine in steers. J. Anim. Sci. 67:262-275.

Van Soest, P. J., J. B. Robertson, and B. A. Lewis. 1991. Methods for dietary fiber, neutral detergent fiber, and nonstarch polysaccharides in relation to animal nutrition. J. Dairy Sci. 74:3583-3597.

Van Straalen, W. M., J. J. Odinga, and W. Mostert. 1997. Digestion of feed amino acids in the rumen and small intestine of dairy cows measured with nylon-bag techniques. Br. J. Nutr. 77:8397.
Varvikko, T. and A. Vanhatalo. 1991. Intestinal nitrogen of hay and grass silage estimated by the mobile nylon bag technique. World Rev. Anim. Prod. 16:73-76.

Varvikko, T., J. E. Lindberg, J. Setala, and L. Syrjala-Qvist. 1983. The effect of formaldehyde treatment of soy-bean and rapeseed meal on the amino acid profiles and acid-pepsin solubility of rumen undegraded protein. J. Agric. Sci. (Camb.) 101:603-612.

Weakley, D. C., M. D. Stern, and L. D. Satter. 1983. Factors affecting disappearance of feedstuffs from bags suspended in the rumen. J. Anim. Sci. 56:493-507. 